\title{
Assessing Geotechnical Risks in the Frame of Landfill Engineering in Eastern Europe
}

\author{
Petra Schneider ${ }^{1,2}$, Klaus-Dieter Oswald ${ }^{2},{\text { Birgitt Wei }{ }^{2} \text { and Rolf Littmann }}^{2}$ \\ 1. University of Applied Sciences Magdeburg-Stendal, Breitscheidstr. 2, D-39114 Magdeburg, Germany \\ 2. C\&E Consulting und Engineering GmbH, Jagdschänkenstr. 52, D-09117Chemnitz, Germany
}

\begin{abstract}
The planning of waste management facilities requires a study of design alternatives including economic and environmental aspects to determine the optimal solution. Both landfill design and engineering are based on a geotechnical risk assessment namely in terms of the stability of the subsoil, the potential of mechanical deformation of the landfill body, and the stability of the interim and final cover considering also seismic events. This contribution introduces sites located in Romania and Estonia with a special focus on the geotechnical risk assessment in the design and construction of new landfills and the closure of old landfills. During the closure of a landfill an appropriate development of the interim cover is of high relevance for the remediation of old landfills, since the settlement processes in the landfill body must be decayed before the final cover can be applied. Depending on the proportion of biodegradable waste in the landfill body, the degree of compaction of the waste as well as the alteration and degree of mineralisation, the degree of the settlements can account for 5 to $15 \%$ of the landfill body height. The major settlements can generally last up to three years, depending on the organic inventory of the landfill. The examples from landfill engineering in Estonia and Romania illustrate the relevance of geotechnical assessments during the design phase of a landfill or a landfill closure as well as during the construction period.
\end{abstract}

Key words: Landfill engineering, geotechnical landfill stability, landfill closure.

\section{Introduction}

As part of the development of a modern infrastructure, the European Commission finances the implementation of integrated waste management systems in the EU (European Union) and its Candidate States. This comprises the development of recycling systems, the construction of new landfills according to EU standards, and the closure of not compliant landfill sites. The framework of the EU waste legislation is assigned by the EU Waste Framework Directive 2008/98/EC [1] and the Landfill Directive 1999/31/EC [2] as well as the regulation on the shipments of waste 1013/2006/EC [3]. The EU Member States, but also candidate States and Turkey enacted laws to implement the requirements of the EU legislation. Generally, the "waste hierarchy" of the EU is to be considered, indicating that waste should be managed in the

Corresponding author: Petra Schneider, Dr., prof., chair for international water management, study course director "ecological engineering". following ways with descending order in the priority:

- Waste prevention or reduction of waste production,

- Reuse of waste by recycling, reuse or recovery or any other treatment to recover secondary raw materials,

- Utilisation as an energy source,

- and only by then landfilling.

In order to ensure the environmental performance desired, a sanitary landfill must contain the standard elements that are meant to eliminate the negative impact to the environment and human health. Newly created landfills are designed according to the multi barrier system at which the barriers

- landfill location/underground

- landfill body (waste) and

- landfill sealing

form the entirety of the concept and guarantee the environmental compatible waste disposal. Therefore, for the construction and the operation of a landfill several criteria are to be considered already from the 
design and planning stage. The search for locations in the frame of site evaluation and planning for new landfills is an interdisciplinary technical challenge. The option analyses serves for the optimisation and the selection of the preferred option. The site evaluation includes the site identification, broad site screening, the detailed scoring of characteristics, the detailed site evaluation and comparison, and the final site decision.

In the search for a location for new landfills following aspects are to be considered: the suitability of the geological subsurface, available areas and capacities, existing connections to media as well as traffic connection, the groundwater level, flood risk, distance to protected commodities like surface waters, residential areas, nature reserves and others, the slope, climatic conditions and the current land-use [4-6]. The geotechnical aspects of the landfill construction address primarily the foundation, the settlement processes, the stability of the landfill body as well as the stability of the intermediate cover and the final cover, as well as considering potential seismic events. The EU Landfill Directive requires that protection of soil, groundwater and surface water is to be achieved by the combination of a geological barrier and bottom liner. The geological barrier is determined by the geological and hydrological conditions to ensure that the underlying soils provide sufficient attenuation capacity to prevent a potential risk to soil and groundwater.

A key aspect is the long-term safety of the functionality of the sealing system [7], in case of the closure of old landfills the surface sealing, as well as the base sealing of new landfills. The major role of a landfill sealing layer is to act as a barrier between waste and the environment and to not allow exchanges between them. Special requirements are given on the remediation of landfills relating to the reclamation, since on the one hand a solution of pollutants from the landfill must be avoided and on the other hand a reintegration in the landscape shall take place.

\section{Methods and Criteria for the Assessment of the Geotechnical Risks at Landfills}

The municipal waste is a mixture of grainy and fibrous components causing particular geotechnical properties. Frictions are generated between the grainy components by shear strain, whereas the fibrous components, similar to reinforcement, absorb tensile stress and thus contribute to the enhancement of the shear resistance. The fibre cohesion rises linear with the load and is limited by the tensile strength of the fibres. In case of an anisotropic fibre distribution, the determination of the appropriate material constants must be carried out by a pressure-regulated tension test [8].

\subsection{Mechanical Properties of Domestic Waste}

The mechanical properties are reflected in the typical geotechnical risk factors for a landfill which are summarised in following assessment criteria:

(a) stability of the subsoil,

(b) mechanical deformation of the landfill body including shear and gliding fracture as well as settlement of the landfill due to biodegradation in the waste body,

(c) stability of the intermediate and final cover.

The abovementioned criteria must be considered during the design and the construction phase. The assessments are supported by investigation of soil mechanical properties in the laboratory, in the field (small scale test plots for base and surface sealings), soil mechanical calculations, and the stability prognosis

Table 1 Mechanical properties of household waste [8].

\begin{tabular}{ll}
\hline Parameter & Properties of domestic waste \\
\hline Density $\left(\mathrm{t} / \mathrm{m}^{3}\right)$ & 0.4 (not compacted)- 1.4 (highly compacted) \\
Friction angle & $40^{\circ}$ (fresh waste)-26 $6^{\circ}(15$ years old waste) \\
Cohesion & $\mathrm{c}=50 \mathrm{kN} / \mathrm{m}^{2}$ (fresh waste) $-10 \mathrm{kN} / \mathrm{m}^{2}(15$ years old waste) \\
\hline
\end{tabular}


for the long term. The general technical characteristics of the abovementioned criteria are given in the following chapters and discussed in detail using site studies performed in Albota (Romania) [9] and Pääsküla (Estonia) [10]. The sites are typical for the situation in Eastern Europe.

\section{Criterion A: Stability of the Subsoil}

Geotechnical investigations for the assessment of the stability of the foundation include the site investigation of soil, rock, fault distribution and bedrock properties to determine their properties. Further are investigated aspects like the risk of earthquakes, landslides and mudflows, sinkholes, soil liquefaction, and rockfall. Bisch et al. [11] introduced the EUROCODE 7 as framework for geotechnical design in Europe. It includes minimum requirements for the extent and content of geotechnical investigations, calculations and construction control checks, in order to consider the complexity of the associated risks (EN 1997-1, 2004, $\S 2.1(8) \mathrm{P})$ [12]. Ground investigation and testing for geotechnical design are covered by EN 1997-2 (2007) [13]. Further, according to EN 1998-1 (2004) [14] the earthquake resistance must be ensured. For the ground investigations are used laboratory tests as are covered by EN 1997-2 (2004) [13]:

- tests for classification, identification and description of soil,

- chemical testing of soil and groundwater,

- strength testing and strength index testing of soil,

- compressibility and deformation testing of soil,

- compaction and permeability testing of soil,

- tests for classification of rocks,

- strength testing and swelling testing of rock material.

According to European Legislation the landfill base and sides shall consist of a mineral layer which satisfies permeability and thickness requirements with a combined effect in terms of protection of soil, groundwater and surface water at least equivalent to one resulting from the following requirements for a landfill for non-hazardous waste: $\mathrm{k}_{\mathrm{f}}<1 \times 10^{-9} \mathrm{~m} / \mathrm{s}$ and thickness $>1 \mathrm{~m}$. The European Landfill Directive permits that, if the naturally occurring soils do not meet the above conditions, the barrier can be completed artificially and reinforced by other means giving equivalent protection. In any event, the artificially established geological barrier should not have a thickness less than $0.5 \mathrm{~m}$. The Directive also requires that both an artificial sealing layer and a drainage layer have to be provided and, for the base of the landfill, the drainage layer must be $\geq 0.5 \mathrm{~m}$. For alternative sealing systems is needed an equivalency proof. According to the applicable technical norms for landfill designs, the natural geological barrier for the base and the slopes must consist of a mineral layer according to the following conditions:

- hazardous waste: thickness $\geq 5 \mathrm{~m}$, permeability $\mathrm{k}_{\mathrm{f}}$ $\leq 1 \times 10^{-9} \mathrm{~m} / \mathrm{s}$;

- non-hazardous waste: thickness $\geq 1 \mathrm{~m}$, permeability $\mathrm{k}_{\mathrm{f}} \leq 1 \times 10^{-9} \mathrm{~m} / \mathrm{s}$;

- inert waste: thickness $\geq 1 \mathrm{~m}$, permeability $\mathrm{k}_{\mathrm{f}} \leq 1$ $\times 10^{-7} \mathrm{~m} / \mathrm{s}$.

If these conditions are not fulfilled in the natural situation, an artificial hydrogeological barrier shall be constructed. If the required quality of clay cannot be found in borrow pits within a reasonable distance from the site and/or the clay is economically less feasible than alternatives with ensured similar quality standards, it is possible to construct the geological barrier in the bottom liner.

\section{Criterion B: Mechanical Deformation of the Landfill Body}

Potential risks in terms of mechanical deformation of a landfill body are summarised in Fig. 1. The main risks are landslides, slope ruptures and settlements [15]. Fig. 2 shows the potential impacts of the different key factors on the mechanical deformation by shear and gliding fractures.

In landfills the organic substance is used as a nutrition source by microorganisms and is partly turned 


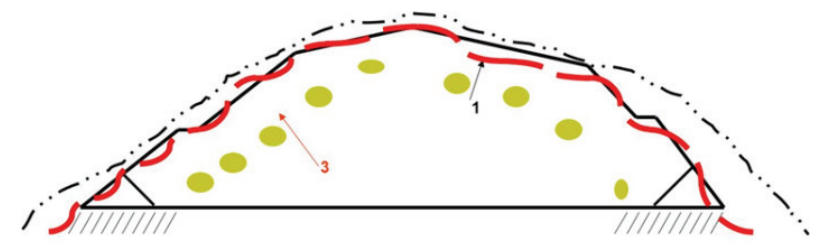

1. Regular Settlement

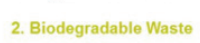

3. Real Settlement

Fig. 1 Potential risks in terms of mechanical deformation of a landfill body.

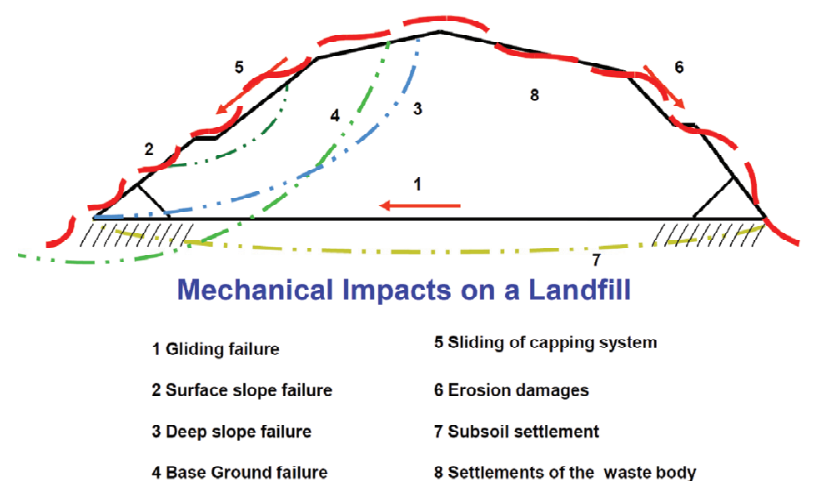

Fig. 2 Resulting settlements of a household waste landfill.

over to landfill gas $[16,17]$. The more biologically degradable carbon the deposited waste contains, the more biomass is degraded generating landfill gas and causing more intense settlements [6, 17-19]. The most mechanical risks can be reduced in the planning process through appropriate technical-engineering measures. The settlement process, however, is time dependent and practical not suggestible. Settlements are caused especially by Refs. [19-21]:

- the weight of the waste,

- additional loads caused by covering layers,

- the degradation rate of the biodegradable waste.

The settlement degree depends on (see figure 2):

- the composition of the waste,

- the volume of the biodegradable waste (organic portion),

- the compaction degree of the waste,

- the mineralisation degree of the waste.

After a biological pre-treatment the pore space is significantly reduced. Thus, the infiltration rate decreases, however, a saturation of the waste can not be avoided in the long-term. Additionally, settlements still occur, so that the principal mechanisms of the creations of excess pore water pressure still remain [8]. Consolidation settlement accounts for maximum 25\% of the total settlement. The most important settlements include, besides the consolidation settlement, the settlement by the loss of volume, the biological decomposition and the subsoil settlement.

The settlement degree can account for 5\% to $15 \%$ of the height of the landfill body (and even higher for fresh waste) $[9,10]$. The settlement process causes:

- a change of the slope inclination,

- a changed surface structure with hollow moulds in which water can accumulate, since the surface runoff is no longer guaranteed,

- a surface sealing system can be harmed and loose its sealing function,

- the gas collection system can be harmed.

A repair of these damages is not feasible since the instauration of the whole layer package including the geomembrane for the preservation of the sealing function would be necessary. One of the most challenging geotechnical risks is the hydraulics in a landfill body. Forensic investigations have shown that the creation of excess pore water pressure is the major cause of slope fractures. These hydraulic conditions appear more frequently at landfills, on which a soil cover of the waste was applied recently. In this process moist and wet waste are covered with inferior soil, which compacts under the landfill load and creates barrier layers. The embedded water will be compressed with an increasing settlement of the landfill, and thus generating excess pore water pressure. The functional chain of mass flows influenced by humidity is summarised in Fig. 3 [8].

A further potential risk for the mechanical deformation of a landfill body are earthquakes [22]. In the course of the harmonisation of European standards also the standard for the design of structures for earthquake resilience EUROCODE 8 was introduced compulsory for the European member states [11]. In the EUROCODE 8 two code cases for buildings are 


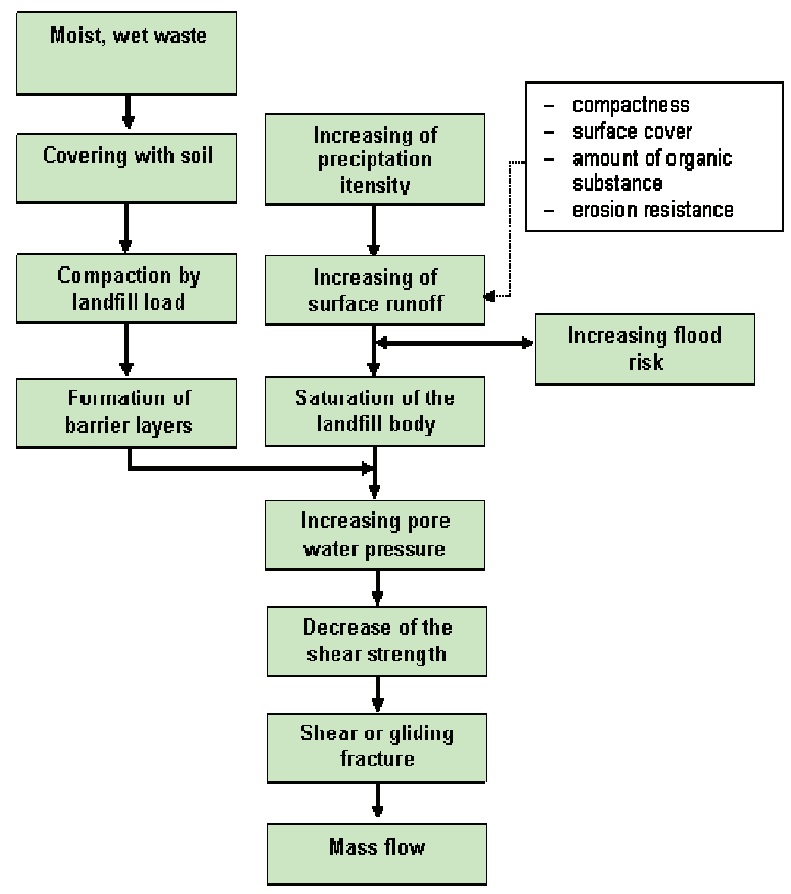

Fig. 3 Functional chain of mass flows influenced by humidity [8].

foreseen. For the verification of the bearing capacity it has to be ensured, that the building resists an earthquake with a mean repeat interval of 475 years (corresponding to an exceeding probability of $10 \%$ in 50 years) without total failure [11]. The main objective is the safeguarding of human lives. The second code case (verification of the serviceability) exposed to small earthquakes, occurring averagely every 95 years (corresponding to $10 \%$ in 10 years) should ensure, that the building does not sustain major damage and thus the financial harm is limited [11]. Turkey and the Balkan countries are among the regions in Europe, which are mostly endangered by earthquakes [23]. The most important settlement mechanisms of a landfill body include:

- physical compaction by mechanical rotation and bending,

- tough behaviour and consolidation,

- biological decomposition of the organic substance (biodegradation of waste),

- migration of small particles on pores between large particles,

- degradation of particles.

\section{Criterion C: Stability of the Intermediate and Final Cover}

The main objective of the sealing is the reduction of the generation of leachate, which must be treated [24, 25]. Besides the improved stability, the reduction of the precipitation infiltration generally also causes a reduction of the pollutant release.

Thereby, pollution of surface and groundwater is prevented or an existing environmental impact can be reduced. Moreover, sealing systems should meet the following requirements:

- low settlement sensitivity,

- protection against erosion,

- long life time with low follow-up costs,

- protection against deep bioturbation,

- site re-integration in the natural surroundings.

Before a landfill receives its final surface sealing, the major settlements must have decayed. This takes up to several years. In the meantime the slopes are provided with an interim soil layer. This measure protects against erosion and prevents the input of precipitation into the landfill body as well as emission of landfill gas into the atmosphere. The geotechnical stability of the intermediate and final cover is one of the main criteria for the environmental long term safety of cover liners of closed landfills.

The inner stability of the landfill body concerns the slope stability, the resistance against expansion pressure, the stability of the basis sealing/surface sealing/drainage and also internal settlements. The outside stability (landfill body-subsoil) concerns rupture phenomena and subsoil settlements. A surface sealing must guarantee an extraordinary long functional period and it must resist physical, chemical and biological influences like [24]:

- temperature fluctuations,

- static and dynamic loads,

- deformations by settlement differences,

- changes in water content,

- precipitation of substances solved in the soil water, 
- chemical aggression of landfill gas, gas condensate, liquid accumulation,

- bioturbation and cryoturbation, as well as

- microbial processes.

The application of an interim cover addresses primarily the minimisation of the water input by rainfall, thus reduces the generation of leachate and prevents or reduces erosion damages by wind and rainfall. Furthermore, an existing interim cover prevents uncontrolled outgassing. Thus, the emission of pollutants can be minimised and thereby the odour nuisance for the environment can be reduced. Moreover, the construction of an intermediate sealing can also prevent an inadvertent introduction of animals, like rats. The intermediate sealing increases the safety against rupture for activities afterwards, since the majority of the settlements occurred before the application of the final sealing.

\section{Investigation Results and Discussion: Criteria Application in Landfill Engineering in Eastern Europe}

In order to highlight the practical implications of the above mentioned problems, selected landfills in Estonia and Romania are discussed below. The geotechnical risk assessment was prepared during the design and construction period of EU funded engineering projects. The collected experiences are presented, as well as the learnt lessons. Fig. 4 shows an overview map of the locations of the discussed landfills:

- Albota landfill near Pitesti in Romania and

- Pääsküla landfill near Tallinn in Estonia.

Criterion A: Stability of the Subsoil-Example of Albota Landfill in Romania

The full range of geotechnical aspects in landfill engineering was encountered during the design and construction supervision of the new urban waste landfill of Pitesti Municipality in Albota as extension of the existing landfill after its closure (also located in Albota) [9]. The relevant Romanian regulation on waste management is MO. 757/2004 regarding the approval of Technical Norms on waste disposal [26].

Location: The urban waste landfill of Pitesti Municipality is located in the Southwest of Pitesti, in the county Arges in the centre of Romania on the old terrace of the Argeş river at an altitude of $355 \mathrm{mNN}$. The location is situated on the foot of Albota hills in an open plain bordered to the Northeast by a draining channel, and to the West and South by plantations and agricultural farms. The Hydrographical Network consists of Valea Turcească Creek, with its right tributary creeks Valea Oancei and Valea Giorocului, having their springs close to the South of the analysed location. Further the site is characterised by some torrent systems with relatively deep beds causing a significant erosion impact. The distance to the closest human settlement is $1.5 \mathrm{~km}$. From seismic point of view, the searched location, as the zone of Pitesti City, is classified in zone " $\mathrm{D}$ ", $\mathrm{Ks}=0.16$ and the corner period is $\mathrm{Tc}=1.0 \mathrm{sec}(\mathrm{P} 100-92)$, describing a high risk to deformation by seismic events.

Since 1966 about 2 million tons of waste were deposited on the Albota landfill without consideration of environmental and technical standards. The area was used in the past for local clay explorations, as the clay layers are located surface near. The old landfill was established in an abandoned depression resulting from

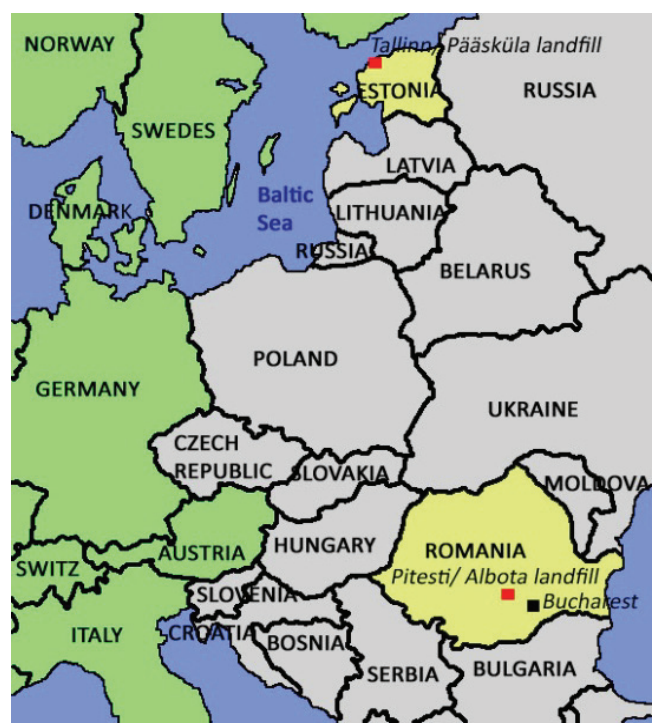

Fig. 4 Location overview of the landfills Albota in Romania and Pääsküla in Estonia. 


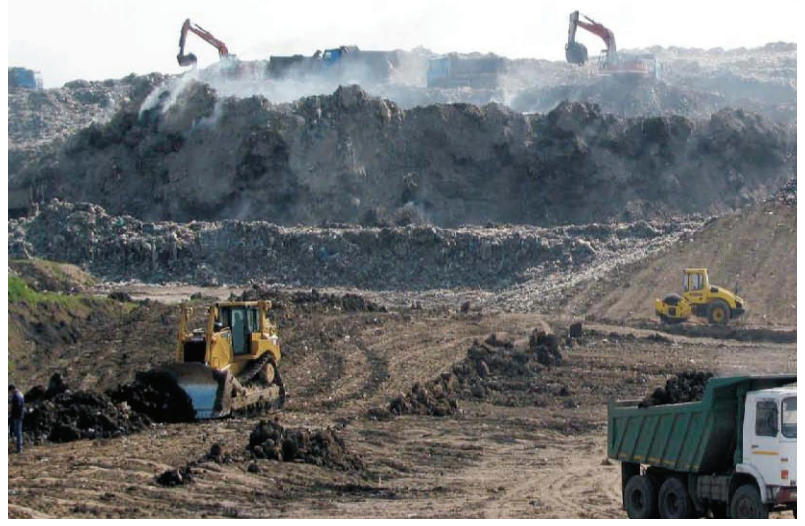

Fig. 5 General impression of the old Albota landfill before the remediation.

clay exploration. The old landfill has a surface of 6.6 ha and a waste thickness of about $30 \mathrm{~m}$. The landfill was closed in 2010. Fig. 5 gives an impression of the location of old landfill in Albota.

One objective of the Feasibility Study was to investigate if the new landfill site with 7.1 ha surface can be prepared directly beside the old landfill site. With this solution could be found a way of optimisation for the use of the location. The scope was to provide the Feasibility Study with variant assessment and environmental impact assessment for the landfill designs. Subject of the design was the closure of the old landfill and the sealing for the planned new landfill as well as the auxillary facilities as access to public transport, administration building, leachate collection and treatment system, composting plant, sorting plant, and civic amenity site. Until 2008 the waste was deposited in North-North-West direction, causing the contour of the landfill as shown in Fig. 6. Further are shown the locations of the drilling program for the subsoil characterisation.

Investigation Approach: The Albota location was investigated in terms of geological and geotechnical characterisation as potential hosting site for the new landfill. The objective was the assessment of the subsoil in terms of geotechnical stability and the usability of the geological setting as natural barrier. The site investigations were followed by the Preliminary Design and the Final Design of the Base
Sealing System for the new landfill and the cover system for the old landfill.

The geotechnical and hydro-geological investigation of the site required 8 boreholes of up to $12 \mathrm{~m}$ depth and related in-situ and laboratory soil tests, including tests of permeability and relevant geotechnical properties as well as the review of existing ground water data. For their location see Fig. 7. The diameter of boreholes

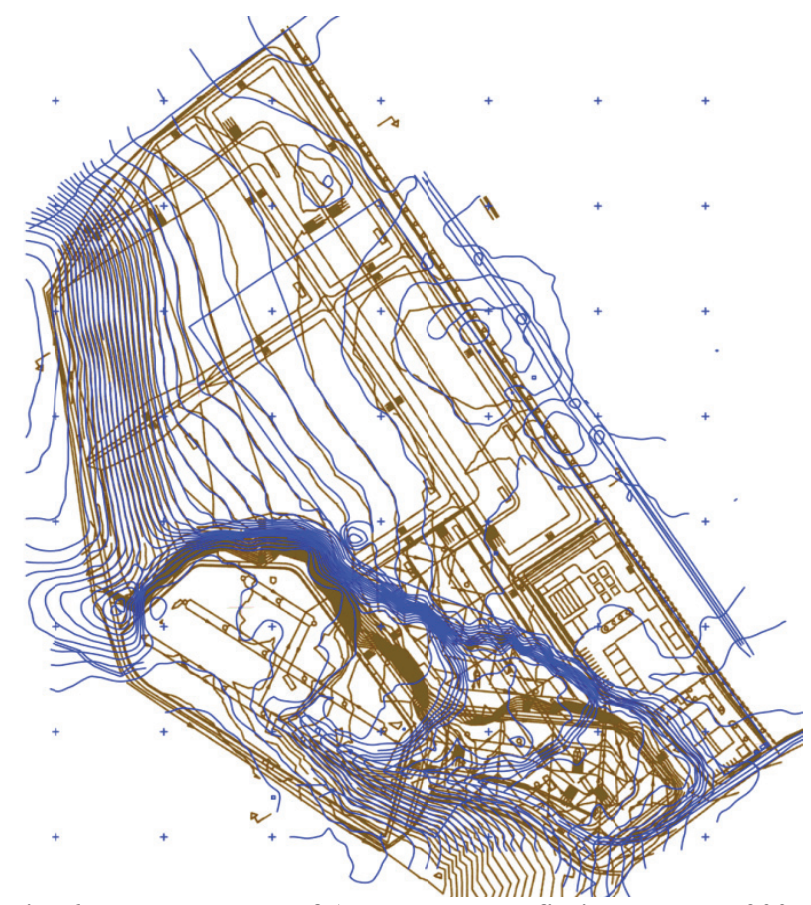

Fig. 6 Development of Albota old landfill in the years 2005 (brown) to 2007 (blue), without scale.

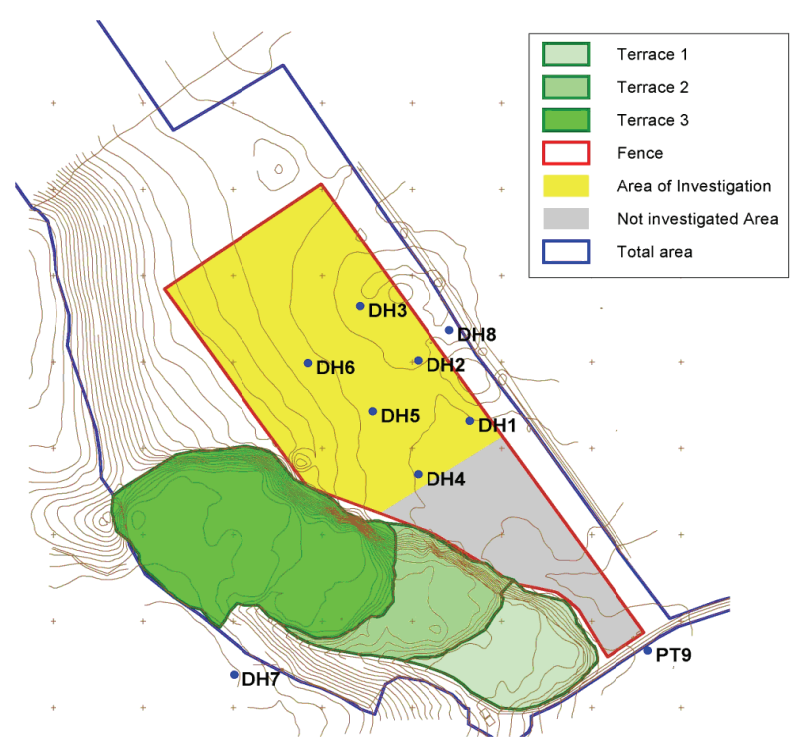

Fig. 7 Drilling program at Albota landfill. 
was $187 \mathrm{~mm}$. In total 13 undisturbed soil samples and 32 disturbed soil samples were taken. Groundwater or landfill leachate water has not been encountered in the drill holes.

The hydro-geological characteristic of the landfill base is given in Table 2. According to the examination of the drill cores the base layers consist of a strong plastic clay with a liquid limit of $\mathrm{wL}=0.3480 \ldots 0.9070$, a plasticity index of IP $=0.1045 \ldots 0.6610$ and $a$ consistency index of $\mathrm{IC}=1.06 \ldots 1.767$.

The results of the hydrogeological and geotechnical investigations show that the subsoil material is not permeable, as well as characterised by a very high compressibility, a high frost susceptibility and a very poor compaction capability. The hydro-geological characteristics of the landfill base are shown in Table 2.

The results in Table 2 were obtained through triaxial test apparatus with a constant hydraulic gradient static load (hydrostatic): $54 \mathrm{KN} / \mathrm{m}^{2}$. Having in view the results of the conducted soil mechanic investigations was concluded that the clay with medium thickness of $4.5 \mathrm{~m}$ (maximum $8 \mathrm{~m}$ ) achieves all criteria for a natural geological barrier and as well the allowance concerning to the construction of a landfill for hazardous waste, seen the geological section in Fig. 8. As shown in the section, the thickness into the south-west direction increases. The basements of the buildings was estimated a maximum settlement of approximate 20 to $40 \mathrm{~mm}$.

Conclusions for the design: The approval of the new landfill site beside the old landfill site was done under consideration of the following aspects:

(a) the location has a history of waste management, (b) the subsoil is formed by clay layers which have a very low permeability and fulfil the requirements for a natural barrier.

After proving the usability of the subsoil as natural barrier confirming also the geotechnical stability the design for the new landfill site was prepared respecting the Romanian legislation. The design included the dimensioning of the dewatering systems based on a water balance calculation for the landfill site. The leachate prognosis is a key design parameter and of basic importance for the sealing stability. For the time period after the closure of the old deposit area a surface sealing system with a compacted clay layer and a drainage layer was designed. The following parameters were assumed:

- $\mathrm{m}$ of recultivation layer with grass cover,

- $0.3 \mathrm{~m}$ of drainage layer ( $\mathrm{kf}$ value $\geq 1 \times 10^{-3} \mathrm{~m} / \mathrm{s}$ ),

- $\mathrm{m}$ of mineral sealing layer (barrier soil, $\mathrm{kf} \leq 1 \times$ $\left.10^{-9} \mathrm{~m} / \mathrm{s}\right)$,

- $10.0 \mathrm{~m}$ Municipal Waste,

- $5.0 \mathrm{~m}$ of subsoil (Barrier Soil, $\mathrm{kf} \leq 1 \times 10^{-9} \mathrm{~m} / \mathrm{s}$ ).

The average precipitation at the site is $661 \mathrm{~mm} / \mathrm{a}$. Due to the grass cover the average evapotranspiration reaches $503 \mathrm{~mm} / \mathrm{a}$. The difference in the water volume percolates through the recultivation layer $(158 \mathrm{~mm} / \mathrm{a})$. An average amount of $139 \mathrm{~mm} / \mathrm{a}$ flows lateral in the drainage layer into the drainage channels. The percolation of the mineral sealing layer is $19 \mathrm{~mm} / \mathrm{a}$ and can theoretically reach the groundwater. With the designed use of a geomembrane the percolation through the surface cover will be reduced to zero.

Technical facilities at the new landfill comprise an administration building with black/white area, scales,

Table 2 Hydro-geological characteristics of the landfill base.

\begin{tabular}{ccccc}
\hline Drill hole & \multicolumn{2}{c}{$\begin{array}{c}\text { Sampling } \\
\text { (m below surface) }\end{array}$} & Thickness & $\mathrm{K}_{\mathrm{r}}$-Value $(\mathrm{m} / \mathrm{s})$ \\
\hline DH 1 (F3) & $2.0-2.3$ & $4.2-4.50$ & $5 \mathrm{~m}$ & $4.0 \times 10^{-10}$ \\
DH 2 (F8) & $1.0-1.3$ & $3.8-4.10$ & $5 \mathrm{~m}$ & $1.6 \times 10^{-9}$ \\
DH 3 (F7) & $1.0-1.3$ & $4.8-5.1 \mathrm{~m}$ & $5 \mathrm{~m}$ & $9.3 \times 10^{-10}$ \\
DH 4 (F4) & $2.0-2.3$ & $4.8-5.1 \mathrm{~m}$ & $5 \mathrm{~m}$ & $9.1 \times 10^{-10}$ \\
DH 5 (F5) & $3.0-3.0$ & $4.8-5.1 \mathrm{~m}$ & $5.2 \mathrm{~m}$ & $7.1 \times 10^{-10}$ \\
DH 6 (F6) & $3.0-3.3$ & & $5.2 \mathrm{~m}$ & $9.1 \times 10^{-10}$ \\
Average & & & & \\
\hline
\end{tabular}




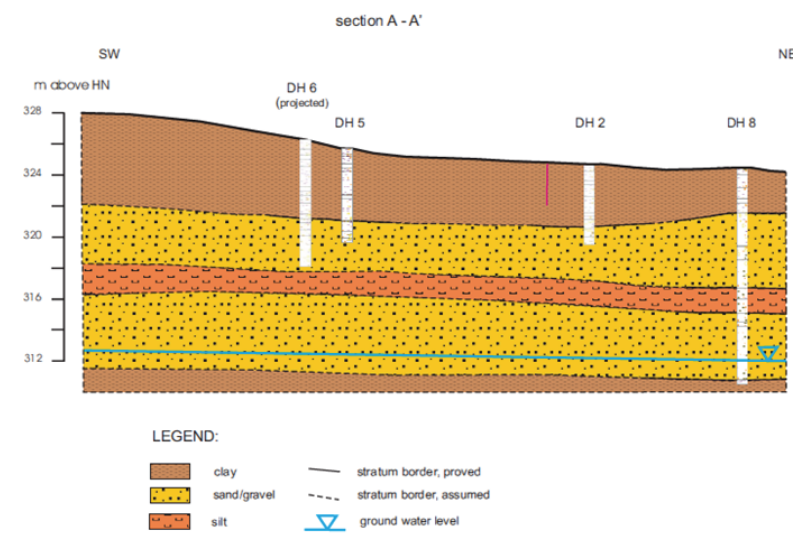

Fig. 8 Geological setting of Albota new landfill site.

delivery stations for domestic and other waste, garage, gas-collecting stations and torch, rainwater retention basin with minimum filling for fire-fighting, leachate treatment plant and sorting plant for the separate collected recyclable fraction. Fig. 9 shows the final design sketch for Albota landfill site.

Fig. 10 gives an impression of the location of the new landfill site in Albota. Within the landfill engineering the old landfill was profiled and partially relocated, supplementary waste was moved to the new landfill.

As MO 757/2004 determines, that a landfill has to be covered in the first step temporarily with a simplified interim cover (soil layer), even that planning approach was put into question by local responsible persons in order to "save" temporarily money. Long term considerations confirmed that such a saving is only temporarily useful as the future repairs of the cover system damaged by differential settlements are more costly. After this, the old landfill was closed using a final cover containing an artificial barrier made of HDPE (high density polyethylene). A HDPE layer was also applied as bottom barrier of the new landfill, seen in Fig. 11.

Criterion B: Mechanical Deformation of the Landfill Body and Criterion C: Geotechnical Stability of the Intermediate and Final Cover-Example of Landfill Pääsküla in Estonia. [10]

Location: Pääsküla landfill was the central municipal waste disposal site for the Harju county in
Tallinn, capital of Estonia, which is the largest town in Estonia with a population of about 400,000 inhabitants [27]. The base of the Estonian waste legislation is the waste act EE JäätS 2004 [28].

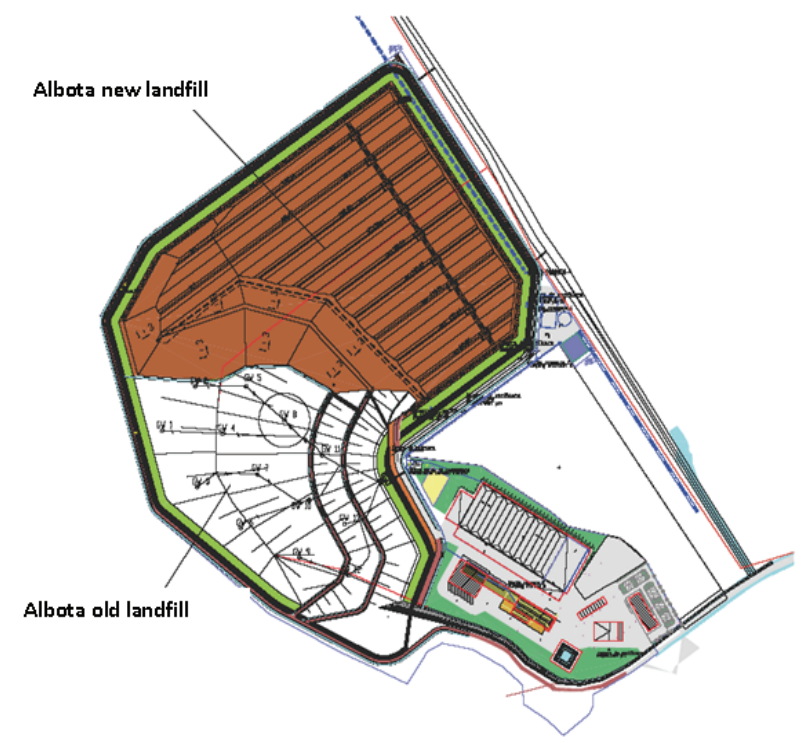

Fig. 9 Final design sketch of the landfill in Albota.

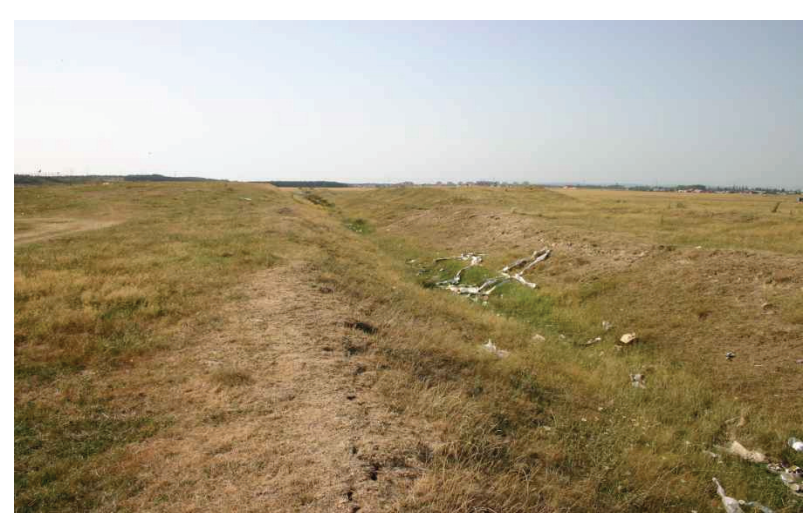

Fig. 10 General impression of the Albota area for the new landfill-Overview on the new landfill area with near-surface clay layers.

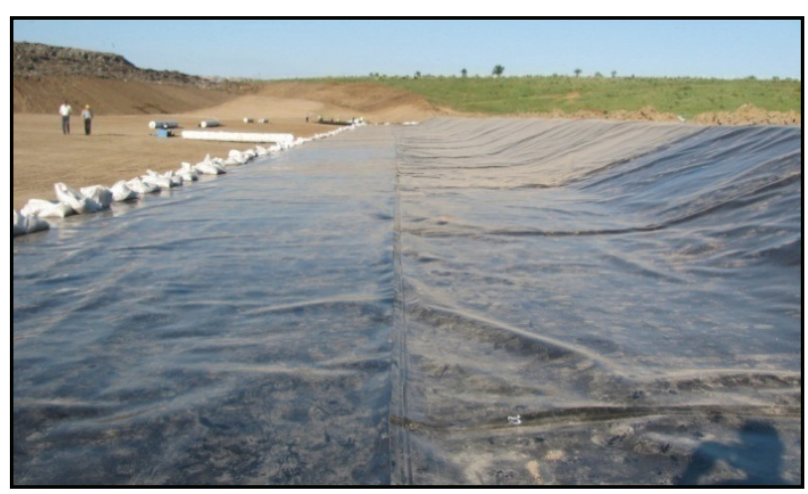

Fig. 11 General impression of the Albota area for the new landfill-Preparation of the base sealing of the new landfill. 
The landfill is located approximately $10 \mathrm{~km}$ South-West of Tallinn City Centre. It was established as a temporary waste deposit in 1972 and since then has been the main deposit of municipal and industrial waste from Tallinn and its suburbs. The landfill covers 28 hectares and was closed in 2005 [29]. The volume of deposited municipal waste is about 4 million tons, including organic waste [30, 31]. Annually 200-220 thousand tons of organic waste are generated in Tallinn, which were also stored in the Pääsküla landfill until 2005.

The site is located in a bog area, underlain by argillaceous limestones from the Upper Ordovician. The landscape is mostly covered with closed needle leaved evergreen forest. In the area of Pääsküla the climate is classified as a humid continental (humid with severe winter, no dry season with a cool temperate moist forest biozone and a high risk of storms) [30]. The risk of slope damage due to surface water from intense storms was very high. The region of Pääsküla has a low earthquake risk ( $\mathrm{V}$ or less, on average one every 50 years), with occurance at $<5$ on the Richter scale.

Fig. 12 provides a general impression of the initial situation of Pääsküla landfill before the application of the interim cover.

After the closure the Pääsküla landfill was temporarily covered with a top sealing, drainage layer and a protective soil layer, reducing the infiltration through the waste to about $50 \mathrm{~L} / \mathrm{m}^{2}$ per year and allowing the clean surface water to drain to Pääsküla river. The final cover was made with a bentonite mat as sealing component and a recultivation cover layer. The long term stability of the landfill slopes was at risk of damage by severe rainfall. Fig. 13 shows the post-remedial situation after the application of the final cover.

Investigation Approach: Having in view the small compaction rate of the waste material, 15 landfill settlement monitoring points have been established in a grid pattern after the interim covering system was installed. Fig. 14 shows the design sketch with benchmarks for settlement monitoring.

The mentioned 15 landfill settlement monitoring locations were observed from August 2004 to October 2006. Fig. 15 shows the settlement charts for the comparison of landfill movements from August 2004 to October 2006. The maximum settlement observed at the measuring location BM 5 southeast part of the landfill centre reached in total $2.5 \mathrm{~m}$ in the period of 2 years.

Small settlement values up to $0.5 \mathrm{~m}$ were observed in the outer periphery of the waste body where the waste volume is much less. In all other parts of the landfill were observed settlement values between 0.75 and $1.25 \mathrm{~m}$. The different measures settlement values on the landfill body resulted in spacious differential settlements which are shown in Fig. 16.

Fig. 16 shows the visualisation of the differential

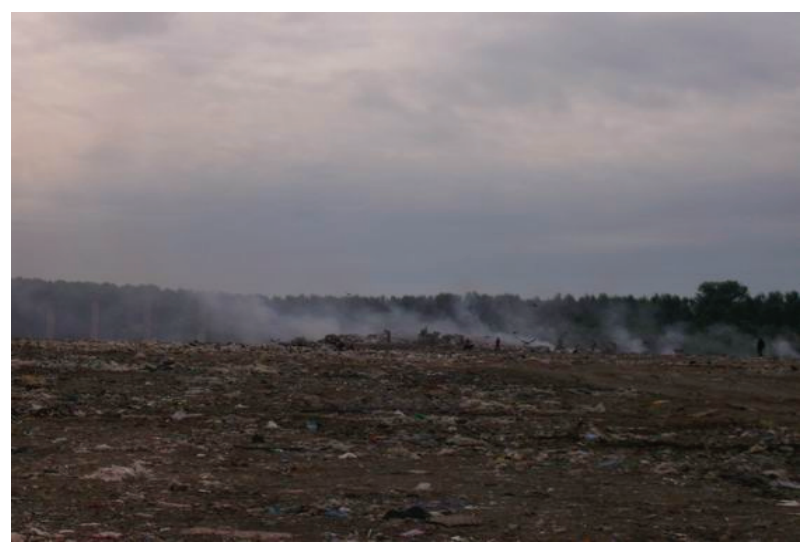

Fig. 12 Initial situation of Pääsküla landfill in Estonia.

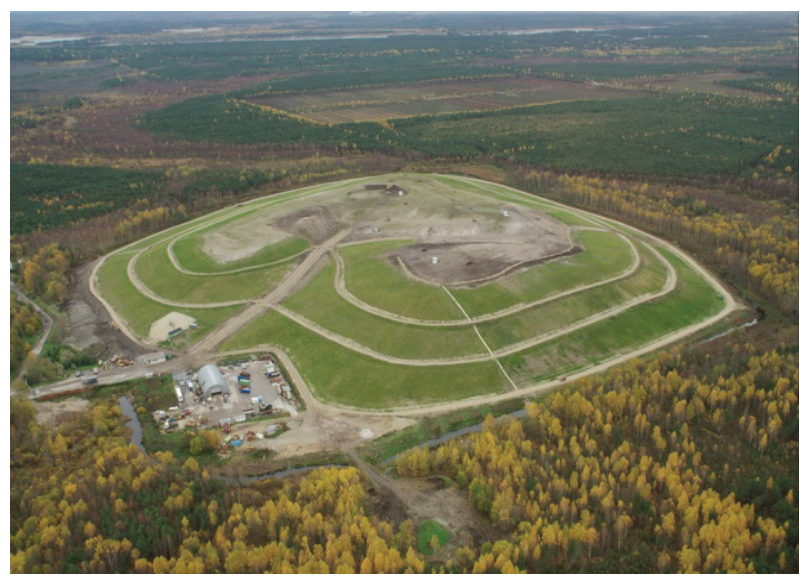

Fig. 13 Post-remedial situation of Pääsküla landfill. 


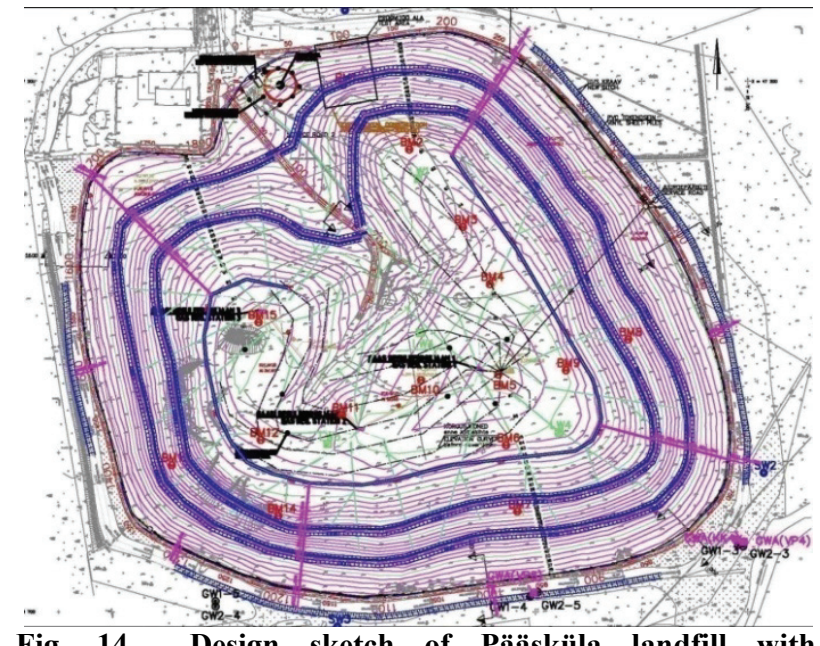

Fig. 14 Design sketch of Pääsküla landfill with benchmarks for settlement monitoring.

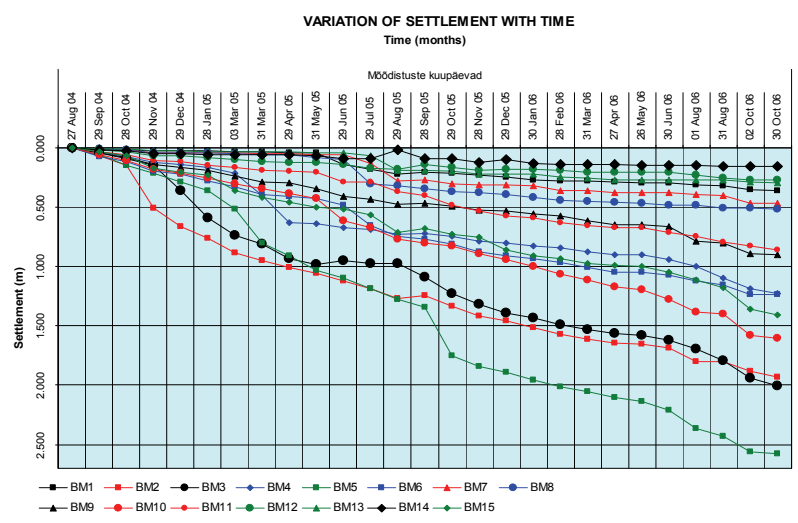

Fig. 15 Settlement charts for the comparison of landfill movements from August 2004 to October 2006 at Pääsküla landfill.

settlements of Pääsküla landfill as a typical settling behaviour of a municipal solid waste landfill body after the closure. The settlements caused by biodegradation of biodegradable waste in the landfill shows in the first half of the year after the closure settlements up to 60 $\mathrm{cm}$, in the course of the year following the closure of up to $1.3 \mathrm{~m}$. Thereafter, the subsidence of the landfill is gradually.

Ten years after the measurement of the differential settlements no further subsidence of the landfill was observed. This observation correlates with a steady trend of decrease of the landfill gas formation from $749,495 \mathrm{Nm}^{3}$ in July 2005 as maximum down to $228,342 \mathrm{Nm}^{3}$ in July 2009 as minimum of the observed period [32], as documented during the landfill during the landfill monitoring, see Fig. 17 [32, 33]. Biogas

\section{Difference Settlements between August 2004 - November 2004}
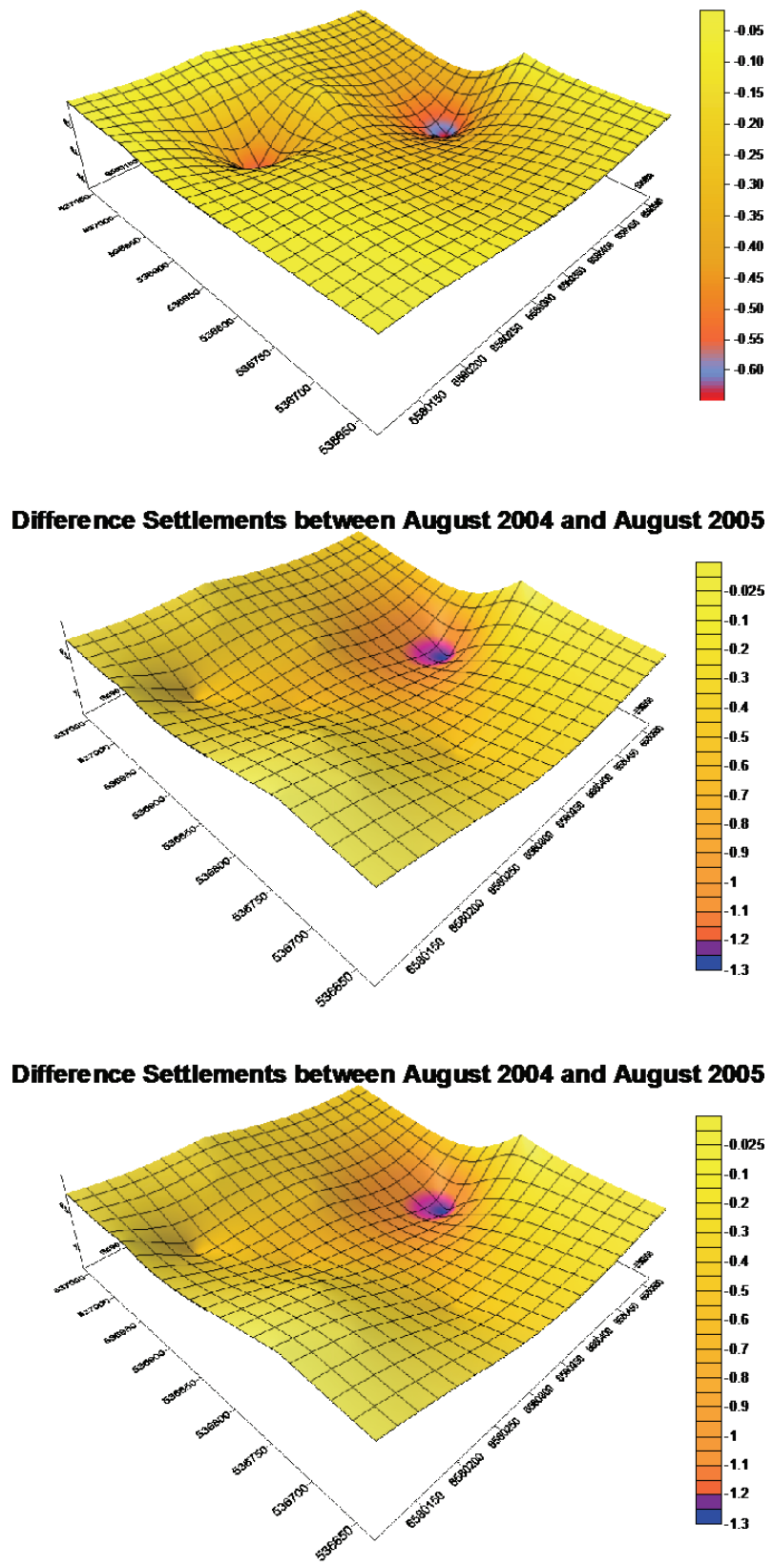

Fig. 16 Differential settlements at Pääsküla landfill in the period 2004-2005.

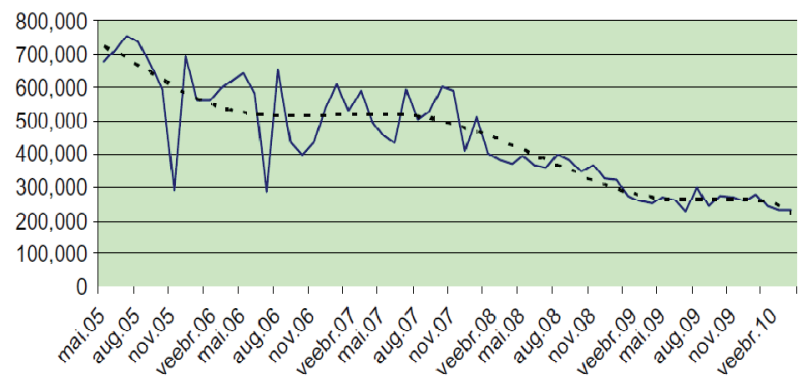

Fig. 17 Biogas production at Pääsküla landfill in the period 2005-2010 [32, 33]. 
production is directly correlated with the decomposition of organic material, which leads to the settlement process of the landfill body.

Conclusions for design and construction: At the time of the tender, it was the general opinion that the landfill had settled to its full extent and that future settlement might only be about $1 \mathrm{~m}$ in the following 30 years. Having in view the large percentage of deposited fatty or wood sludge [29], a larger area with differential settlements was needed to be expected. Consequentially was established the monitoring grid with settlement markers. The values measured in the reality reached in total $2.5 \mathrm{~m}$ in the period of 2 years in the area of the waste body center.

As settlements are mainly caused by the own weight of the landfill material, additional loads from cover layers and the degradation of biodegradable waste these issues must be considered during the design phase in a comprehensive way. The optimal solution for the remediation of old landfills is the application of an interim cover made of soil, since the settlement processes in the landfill body must be decayed before the final cover can be applied. This must be already considered in the closure design.

\section{Conclusions of the Case Studies}

The planning of waste management facilities requires a study of design alternatives including economic and environmental aspects to determine the optimal solution. Both landfill design and engineering are based on a geotechnical risk assessment namely in terms of the stability of the subsoil, the potential of mechanical deformation of the landfill body, and the stability of the interim and final cover considering also seismic events.

With regard to the geotechnical risks special attention must be turned on the appropriate construction of the sealing systems, i.e. the basis and the surface sealing as well as the interim cover. In the shown examples, based on settlement measurements, the decay of the settlement takes at least 2 years dependent on the grade of compression and the grade of mineralisation of the waste. Due to different waste heights in the area of the slopes and the plateau, but also due to differences in the waste composition, the settlement amounts are not equal in the whole landfill body. During the closure of a landfill an appropriate development of the interim cover is of high relevance for the remediation of old landfills, since the settlement processes in the landfill body must be decayed before the final cover can be applied. Depending on the proportion of biodegradable waste in the landfill body, the degree of compaction of the waste as well as the age and degree of mineralisation, the amount of the settlements can account for 5 to $15 \%$ of the landfill body height.

The closure of a settlement endangered landfill without an interim cover involves the risk to pay twice for the closure. Therefore, at the recultivation of landfills an interim sealing is essential in the period of the decay of the settlement of the landfill body, before the final sealing can be implemented. While in Germany the interim cover is stated in the landfill regulations and is generally applied especially for large landfills, the international situation is different. In Estonia and Lithuania, there was no provision for an interim cover stated in the legislation. After experiences with landfill closures, a separate guideline, based on German experiences was established. In Romania, for example, the interim cover is stated in the national landfill regulation MO 757/2004 (settlements should be waited out for 2 to 5 years), in reality the application of an interim cover is often refused, due to short-term cost considerations. Hence, the subject is constituted differently in the international comparison. In Asian countries this subject is not stated in the legislation.

\section{References}

[1] Waste Framework Directive, or Directive 2008/98/EC of the European Parliament and of the Council of 19 November 2008 on waste and repealing certain Directives.

[2] Council Directive 1999/31/EC of 26 April 1999 on the landfill of waste.

[3] Regulation No. 1013/2006/EC of the European Parliament and of the Council of 14 June 2006 on shipments of waste.

[4] Daniel, D. E. 1993. "Landfills and Impoundments." In 
Geotechnical Practice for Waste Disposal, edited by Daniel, D. E. London: Chapman and Hall, 97-112.

[5] Oeltzschner, H. 1992. "Anforderung an Die Geologie, Hydrogeologie und Geotechnik Beim Bau von Deponie." In Abdichtung von Deponien und Altlasten, edited by Thorme-Kozmiensky, K. J. Berlin: E. F. Verlag fur Energie und Umwelttechnik GmbH, 53-82.

[6] Qian, X., Koerner, R. M., and Gray, D. H. 2002. Geotechnical Aspects of Landfill Design and Construction. Upper Saddle River. N.J: Prentice Hall.

[7] Heerten, G., and Koerner, R. M. 2008. "Cover Systems for Landfills and Brownfields." Land Contamination \& Reclamation 16 (4): 343-56. doi: 10.2462/09670513.904.

[8] Kölsch, F. 1996. "The Impact of Fibres on the Shear Strengths of Municipal Waste.” Ph.D. thesis, Technical University Braunschweig, Germany.

[9] C\&E. 2011. "Technical Assistance for Management and Supervision ISPA Contracts in the Solid Waste Sector in Arges, Romania.” ISPA 2005 RO 16 P PE 001, C\&E Consulting und Engineering $\mathrm{GmbH}$.

[10] C\&E. 2006. "Tallinn Waste Management-Phase II; Closure of Pääsküla Landfill, Tallinn, Estonia." EUROPEAID/113974/D/SV/EE, C\&E Consulting und Engineering $\mathrm{GmbH}$.

[11] Bisch, P., Carvalho, E., Degee, H., Fajfar, P., Fardis, M., Franchin, P., Kreslin, M., Pecker, A., Pinto, P., Plumie, A., Somja, H., and Tsionis, G. 2012. "Eurocode 8: Seismic Design of Buildings - Worked Examples." Presented at the Workshop "EC 8: Seismic Design of Buildings", Lisbon, 10-11 Feb. 2011, Support to the Implementation, Harmonization and Further Development of the Eurocodes, JRC Scientific and Technical Reports, EUR 25204 EN-2012.

[12] EN 1997-1 2004. (English): Eurocode 7: Geotechnical Design-Part 1: General Rules, Authority: The European Union Per Regulation 305/2011, Directive 98/34/EC, Directive 2004/18/EC.

[13] EN 1997-2 2007. (English): Eurocode 7: Geotechnical Design-Part 2: Ground Investigation and Testing, Authority: The European Union Per Regulation 305/2011, Directive 98/34/EC, Directive 2004/18/EC.

[14] EN 1998-1 2004. (English): Eurocode 8: Design of Structures for Earthquake resistance-Part 1: General Rules, Seismic Actions and Rules for Buildings, Authority: The European Union Per Regulation 305/2011, Directive 98/34/EC, Directive 2004/18/EC.

[15] Blight, G. 2008. "Slope Failures in Municipal Solid Waste Dumps and Landfills: A Review." Waste Management \& Research 26 (5): 448-63.

[16] Soporan, M. B. V., Soporan, V. F., Bătrînescu, G., and Cociş, E. 2013. "Assessment Methodology for Non-Compliant Landfills." Environmental Engineering and Management Journal 12 (2): 387-91.

[17] Bogner, J. E. 1990. "Controlled Study of Landfill Biodegradation Rates Using Modified BMP Assays." Waste Management \& Research 8: 329-52.

[18] Dixon, N., Langer, U., and Gotteland, P. 2008. "Classification and Mechanical Behavior Relationships for Municipal Solid Waste: Study Using Synthetic Waste." ASCE J. Geotech. Geoenviron. Eng. 134 (1): 79-90.

[19] Gabr, M. A., and Valero, S. N. 1995. "Geotechnical Properties of Municipal Solid Waste." Geotechnical Testing Journal, ASTM 18 (2): 241-51.

[20] Durmusoglu, E., Sanchez, I. M., and Corapcioglu, M. Y. 2006. "Permeability and Compression Characteristics of Municipal Solid Waste Samples.” Environmental Geology 50: 773-86

[21] El-Fadel, M., and Al-Rashed, H. 1998. "Settlement in Municipal Solid Waste Landfills 1." Field Scale Experiments, Journal of Solid Waste Technology and Management 25 (2): 89-98.

[22] Zania, V., Tsompanakis, Y., and Psarropoulos, P. N. 2008. "Seismic Distress and Slope Instability of Municipal Solid Waste Landfills." Journal of Earthquake Engineering 12 (2): $312-40$. http://dx.doi.org/10.1080/13632460701574605.

[23] Giardini, D., Woessner, J., Danciu, L., Cotton, F., Crowley, H., Grünthal, G., Pinho, R., Valensise, G., Akkar, S., Arvidsson, R., Basili, R., Cameelbeck, T., Campos-Costa, A., Douglas, J., Demircioglu, M. B., Erdik, M., Fonseca, J., Glavatovic, B., Lindholm, C., Makropoulos, K., Meletti, C., Musson, R., Pitilakis, K., Rovida, A., Sesetyan, K., Stromeyer, D., and Stucchi, M. 2013. "Seismic Hazard Harmonization in Europe (SHARE): Online Data Resource.” doi: 10.12686/SED-00000001-SHARE.

[24] Pohontu, C., Cretescu, I., Secula, M. S., Paduraru, C., Tofan, L., and Macoveanu, M. 2010. "Integrated Treatment of Leachate from Municipal Waste Solid Landfill." Environmental Engineering and Management Journal 9: 95-100.

[25] Schiopu, A-M., and Gavrilescu, M. 2010. "Municipal Solid Waste Landfilling and Treatment of Resulting Liquid Effluents." Environmental Engineering and Management Journal 9 (7): 993-1019.

[26] MO. 757/2004 (OJ No. 86/26.01.2005) Regarding the Approval of Technical Norms on Waste Disposal as Amended.

[27] Põldnurk, J. 2011. "A Descriptive Analysis of Post-Closedown Environmental Monitoring and Maintenance of the Pääsküla Landfill.” Management of Environmental Quality an International Journal 22 (6): 769-86. doi: 10.1108/14777831111170867.

[28] Jäätmeseadus-Estonian Waste Act [EE JäätS 2004] adopted in 2004. 
[29] Kängsepp, P. 2000. "Requirements for the Closure of Old Landfills-Towards Sustainable Landfilling in Estonia." Master thesis, Lund University International Master's Programme in Environmental Science (LUMES). http://www.lumes.lu.se/sites/lumes.lu.se/files/kangsepp_p ille.pdf (assessed 1101.2017).

[30] Selberg, A. 2010. "Evaluation of Environmental Quality in Northern Estonia by the Analysis of Leachate." Ph.D. thesis, the Institute of Chemistry, Faculty of Science and Technology, University of Tartu, Estonia.

[31] Selberg, A., Viik, M., Peet, K., and Tenno, T. 2005. "Characteristics and Natural Attenuation of the Pääsküla
Landfill Leachate." Proc. Estonian Acad. Sci. Chem 54: 35-44.

[32] Tiidemann, I. 2005-2010. "Monthly Reports of the Biogas Production by the Gas Collection System Operator AS TERTS within the Period of May 2005 till May 2010.” Available at: Tallinn Environment Department on Demand.

[33] Kivimägi, J. 2011. "A Descriptive Analysis of Post-Closedown Environmental Monitoring and Maintenance of the Pääsküla Landfill.” Management of Environmental Quality: An International Journal 22 (6): 769-86. http://dx.doi.org/10.1108/14777831111170867. 